\title{
Growth Mindset in Teaching: A Case Study of a Finnish Elementary School Teacher
}

\author{
Rina Ronkainen ${ }^{1}$ \\ Tallinn University \\ Tallinn, Estonia \\ Elina Kuusisto \\ University of Helsinki \\ Helsinki, Finland \\ Kirsi Tirri \\ University of Helsinki \\ Helsinki, Finland
}

\begin{abstract}
This study investigates how a growth mindset is actualised in one first-grade teacher's classroom. Mindset refers to implicit beliefs that individuals hold about basic human qualities. A person with a growth mindset sees these qualities as malleable and subject to development, whereas a person with a fixed mindset sees these qualities as static and unalterable. Previous research has shown that teachers' mindsets have an influence on their pedagogical thinking and practice. The data in this study include classroom observations, videotaping and stimulated recall interviews. Deductive content analysis was used in the inquiry. The teacher's growth mindset pedagogy was actualised with one student in particular when the teacher gave critical feedback in the form of "not yet". This gradually changed the student's fixed mindset behaviour towards a growth mindset. The teacher's growth mindset was also actualised in the class as a whole when she fostered students' process-focused thinking with concrete and immediate praise, indicating her high expectations. The teacher studied can be regarded as an example of a growth-mindset teacher, and her actions and reflections on the teaching-studyinglearning process provide illuminating examples of growth mindset pedagogy in classroom interactions.
\end{abstract}

Keywords: Growth mindset; growth mindset pedagogy; elementary school teacher; Finland.

\footnotetext{
${ }^{1}$ Corresponding author: Rina Ronkainen, rinaron@tlu.ee
} 


\section{Introduction}

This study investigates how a growth mindset is actualised in one Finnish elementary school teacher's practice. The framework for the study comes from Carol Dweck's $(2000,2006)$ theory of mindsets, which investigates the implicit beliefs individuals hold about basic human qualities such as intelligence, personality and abilities. These implicit beliefs have been shown to influence a teacher's pedagogical thinking and practices (Rissanen, Kuusisto, Hanhimäki, \& Tirri, 2018a).

Dweck (2000) has divided mindsets into two categories: a growth mindset and a fixed mindset. A person with a growth mindset believes that basic human qualities such as ability, intelligence and personality are malleable and can be developed, whereas a person with a fixed mindset believes that human qualities are stable and unalterable. Different mindsets also explain why people with equal abilities set different goals and, in similar situations, demonstrate different behavioural patterns. According to previous studies, people with a growth mindset highlight learning goals ("becoming smart", "improving abilities"), appreciate effort and understand failure as a learning opportunity. A growth mindset is also linked with a mastery-orientated attitude towards failures, which means that an individual focuses on the learning process and on understanding the significant components of learning (Dweck \& Leggett, 1988; Kamins \& Dweck, 1999). By contrast, people with a fixed mindset emphasise performance goals ("looking smart", "proving their abilities") and are associated with a negative attitude towards mistakes; they see effort and failure as showing lack of intelligence or ability (Dweck \& Leggett, 1988; Mangels, Butterfield, Lamb, \& Good, 2006). Studies by Blackwell, Trzesniewski and Dweck (2007) and by Yeager and Dweck (2012) have also indicated that people with a fixed mindset persist in helpless behaviour patterns, leading to an avoidance of challenges and a low level of perseverance. Generally, people have a tendency to lean towards either a growth mindset or a fixed mindset, but it is also common to find different mindsets related to various domains (see e.g. Kuusisto, Laine, \& Tirri, 2017) and situations (Rissanen et al., 2018a). Mindsets have been found to be relatively stable and still alterable, and even brief interventions or manipulations have had long-lasting influence on students' motivation and school achievements (Blackwell et al., 2007; Paunesku, 2013).

\section{Growth mindset in teaching}

One of the most frequently cited factors explaining the quality of an educational system is the quality of its teachers (Malinen, Väisänen, \& Savolainen, 2012). The teaching profession is highly respected in Finland, and teachers have a great deal of autonomy. They are also held accountable to high standards in the Finnish educational system (Sahlberg, 2007; Tirri, 2014). The daily contributions of great teachers (Sahlberg, 2014, p. 70) and their excellent pedagogical leadership have been identified as key factors in explaining Finland's success in such areas as the OECD's PISA Global Competence Assessment. Another essential reason for Finland's success in the educational field is the principle of "equal opportunities and high-quality education for all" (Tirri, 2014). The National Core Curriculum for Basic Education (2016) is the foundation for teaching and guides teachers in their daily work. Teachers are expected to enhance 
students' learning while simultaneously being challenged to revise their classroom practices to adapt their teaching to the students' needs (Soini, Pietarinen, \& Pyhältö, 2016). Because a teacher's mindset plays a major role in supporting and advancing a student's learning process (e.g. Schmidt, Shumov, \& Kackar-Cam, 2015) as well as in teachers' pedagogical thinking and practices (Rissanen et al., 2018a), the topic of teachers' mindsets merits careful examination.

Teachers who have a growth mindset endeavour to get to know their students as individuals, provide emotional support and help students find suitable study methods. A mastery-orientated atmosphere, one that fosters learning goals, praises courage, strategies and efforts, and motivates through encouragement and emotional support are examples of a growth mindset pedagogy (Rissanen, Kuusisto, Tuominen, \& Tirri, 2019). This kind of pedagogy serves as the theoretical framework for the present study, which explores a teacher's work in the classroom. The core features of a growth mindset pedagogy can be described as having four main components: (1) support for students' individual learning processes, (2) promotion of mastery orientation, (3) persistence on the part of the teacher and (4) fostering students' process-focused thinking.

Supporting students' individual learning processes refers to a teacher's knowledge of how each student learns and the barriers each faces in order to overcome these. It also means that the teacher takes time for one-on-one interactions with students in order to support their individual learning processes (Rissanen et al., 2019.) Teachers with a growth mindset know their students as individuals, give them emotional support and help them find suitable study methods (Rissanen et al., 2018a).

Promoting mastery orientation means that teacher has high expectations and persistence in fostering learning goals (Rissanen et al., 2019). Also, according to Rissanen et al. (2018a), teachers with a growth mindset tend to foster learning goals in a mastery-orientated atmosphere in order to motivate their students. Supporting students' engagement in learning (Rattan, Good, \& Dweck, 2012), which can be seen as an act of promoting mastery orientation, is an important predictor of students' achievement and behaviour in school (e.g. Klemm \& Connell, 2004).

Giving honest critical feedback in the form of "not yet" and showing students that the teacher is not giving up on them exemplify teacher's persistence. Instead of giving a number grade when a student is failing an exam, if a teacher writes "not yet", students do not feel ashamed because they know that they are expected to pass the next time (Dweck, 2010). According to Dweck (2010), teachers should systematically use the word "yet" in their teaching. For example, if a student says that he/she does not like a subject, the teacher could remark "You don't like it yet". Using the word "yet" let students know that their abilities and motivations are malleable.

Further, fostering students' process-focused thinking can be demonstrated by praising courage, strategies and effort as well as by teaching the positive role 
and interpretation of failures, mistakes and challenges in learning (Rissanen et al., 2019). Teachers' feedback related to process has been found to be more common among growth-mindset teachers than among those with a fixed mindset (De Kraker-Pauw, Van Wesel, Krabbendam, \& Van Atteveldt, 2017).

The study by Rissanen et al. (2019) found critical points in growth mindset pedagogy that represent situational variation and possible pitfalls to be considered in pre- and in-service teacher education. The first has to do with the teacher's trait-focused interpretations of students' personalities and academic success. For example, a teacher's incremental beliefs and process-focused thinking can be stronger in the domain of academic learning and weaker in the domain of personality. A teacher might emphasise the quality of the teachingstudying process whenever she explains students' learning but make more traitfocused interpretations of students' psychological qualities and personality traits.

A second critical point appears when a teacher fails to recognise and actively counter students' fixed mindset behaviours. A teacher might, for example, misread students' fixed mindset behaviour as 'overconfidence' or personality traits and lack persistence and emotional support. A third critical point emergences when a teacher rely on the motivating power of success. A teacher does not teach all students how to cope with failures, but instead prevent some students from taking on challenges. A teacher might, for example, choose to protect academically competent students from challenges if she believes that failure or mistakes would cause the student emotional distress (Rissanen et al., 2019). However, all students and especially talented students benefit if they practise making errors and learn to love challenges (Dweck, 2010). With the help of a teacher, students can learn to interpret mistakes as learning opportunities. The teacher emphasises and highlights achievements and victories, while a growth mindset actually develops when mistakes are not seen as something to be dreaded but may even be praised by the teacher (Boaler, 2015).

A growth mindset pedagogy provides a framework for teachers to use actions according to a growth mindset in the classroom environment. The growth mindset of teachers plays an essential role in their actions and, as well, influences the students' learning. For example, Schmidt, Shumow and KackarCam's study (2015) indicates that when a teacher emphasises mastery goals, reminds students of the growth mindset theory and uses learning strategies in daily classrooms interactions, the students have better outcomes than with a teacher who sends fixed mindset messages. However, Kristjánsson (2008) notes that, for example, a single feedback, no matter what kind it is, cannot be as meaningful as the whole school context for a student's personality development. This indicates the significance of the teachers' mindset, which is shown not only in her feedback and teaching practices, but also in the teacher's attitudes, manners, beliefs and leadership, which affect the classroom atmosphere and the teaching-studying-learning processes. According to Rissanen et al. (2018a), teachers with a growth mindset have a tendency to take responsibility for students' personal development as well as for meeting individual needs. 
Typically, Finnish teachers view themselves as professionals whose task is both to teach basic knowledge and to enhance students' holistic education and wellbeing (Tirri, 2014). Teacher should be able to see a student's abilities, potential and chances to succeed now as well in the future. The Finnish National Core Curriculum for Basic Education (2016, p. 15) emphasises that every student has the right to realise their full potential in a school environment that encourages and supports each student in their individual needs and with caring for the students' learning and well-being. The National Core Curriculum for Basic Education (2016) has elements that endorse a growth mindset pedagogy among teachers.

The present study investigates a growth mindset pedagogy implemented in one Finnish class in a teacher training school that can be regarded as exemplifying Finnish elementary school and Finnish teacher education. The study set out to answer the following research question: How is a growth mindset actualised in teaching practices?

\section{Data and methods}

This study examines one first grade class teacher who works in a Finnish elementary school. The data for this study was collected using multiple research methods like classroom observations, videotaping, critical incident method and stimulated recall (STR) interviews. The teacher was chosen for this study since she had a growth mindset according to earlier research results.

\subsection{Study design}

This study has been carried out as part of a larger research project called "Changing Mindsets about Learning: Connecting Psychological, Educational, and Neuroscientific Evidence" (CoPErNicus). The data for the present study were collected at the University of Helsinki's Viikki Teacher Training School. Firstly, the school's teachers $(n=63)$ responded to eight statements taken from Dweck's inventory (Dweck, 2000; see also Kuusisto et al., 2017). They were asked to evaluate their attitudes about intelligence and giftedness on a six-point Likert scale $(1=$ strongly agree, $6=$ strongly disagree). Mean scores of $1.0-3.0$ referred to a fixed mindset; scores of 3.1 - 3.9 indicated a mixed mindset and scores of 4.06.00 indicated a growth mindset. Based on results of the survey, one teacher, Mari (pseudonym), who had a growth mindset about both intelligence and giftedness $($ mean $=5)$, was chosen for classroom observation and qualitative interviews.

At the time the research was conducted, Mari was teaching first-grade students. Her class included 19 seven-year-olds: eight girls and eleven boys. Mari had a master's degree in education and was qualified as a class teacher in elementary school (grades 1 to 6). Mari was a skilled class teacher with 18 years of experience. She also worked as a teacher educator supervising student teacher in her classroom. Thus, Mari can be regarded as exemplifying the ideals of Finnish basic education and teachers' growth mindset.

\subsection{Data collection and analysis}


The data for this research were collected utilising multiple research methods: classroom observations, videotaping, critical incident method and stimulated recall (STR) interviews. Before the actual data gathering, the researcher spent three days in the classroom practising observation skills and data collection. This allowed the researcher to become acquainted with the teacher, the class and the methods chosen as well as the practicalities of video research. The data gathering was carried out in December 2016 and January 2017. Altogether, the researcher observed teaching for five days from Monday to Friday between 8:00 am to 2:00 pm. The data include 15 hours of classroom interactions and 1 hour and 43 min of STR interviews.

The critical incidents in classroom interactions chosen by the researcher during the observations and videotapings were related to Dweck's (2000) theory of growth mindset. The analysis started during observations and Dweck's theory was utilised as a deductive tool (Elo \& Kyngäs, 2008) to identify mindset-related interactions in the classroom. Videotapes were used in the STR interviews during which the teacher was shown critical incidents from her lessons and was asked to reflect freely on these events. Use of video-stimulated recall method made it possible to capture and investigate the dynamic nature of teachingstudying-learning -process (see Huang, 2014). In total, 17 mindset-related critical incidents were identified. Stimulated recall interviews were chosen, as according to Shulman (1986, p. 23), to understand a teacher's actions in the classroom, it is important to study their thought processes, evaluations, problem-solving strategies and decision-making skills at different phases of the teaching process. STR interview is a beneficial method for studies that investigate cognitive processes, like strategic behaviours in teaching (Huang, 2014).

Growth mindset-related critical incidents were found in Mari's interactions with individual students and with the whole class. In this paper, we present the interactions between Mari and one student, Henri (pseudonym). Henri was a student whose behaviour reflected a fixed mindset; it was in her interactions with this student that Mari's growth mindset was most visible during the week of observations. Moreover, Mari's interaction with the whole class further illustrated her growth-mindset orientation.

\section{Results}

\subsection{Growth mindset in a leading individual's learning process: The Case of Henri}

Mari's growth mindset was evident when she was interacting with individual students (Table 1), especially with one student, Henri, who seemed to hold a fixed mindset about learning. Henri was a seven-year-old who had been in a socalled "forest preschool", meaning that most of the activities were conducted outdoors in a real forest. In Henri's case this background was visible for example, in his feeble fine-motor skills and his impatience at having to sit still for a long time.

The first critical incident involving Henri took place during an art class when Henri and the other students were drawing pictures of snow castles. Not long 
after everyone began to draw, Henri walked up to Mari to show her his picture. Mari looked at Henri's work and said,

"Looks like a very good beginning, but it is not yet ready." (Critical incident 6, Data observation)

Table 1: Teachers' practices and their actualisation in a growth mindset pedagogy

\begin{tabular}{|c|c|c|}
\hline $\begin{array}{l}\text { Mari's teaching practices } \\
\text { in relation to }\end{array}$ & $\begin{array}{l}\text { Actualisation of growth } \\
\text { mindset pedagogy in } \\
\text { Mari's teaching }\end{array}$ & $\begin{array}{l}\text { Growth mindset } \\
\text { pedagogy's key factors } \\
\text { identified by Rissanen et } \\
\text { al. }(2019, \text { p. } 206)\end{array}$ \\
\hline \multirow[t]{5}{*}{ The individual student } & $\begin{array}{l}\text { Knowing a student's } \\
\text { strengths and weaknesses } \\
\text { and taking into } \\
\text { consideration a student's } \\
\text { individual needs }\end{array}$ & \multirow[t]{2}{*}{$\begin{array}{l}\text { Supporting student's } \\
\text { individual learning } \\
\text { processes }\end{array}$} \\
\hline & $\begin{array}{l}\text { Intervention right away } \\
\text { when the teacher noticed } \\
\text { fixed mindset behaviour }\end{array}$ & \\
\hline & $\begin{array}{l}\text { Critical feedback in the } \\
\text { form of "not yet" }\end{array}$ & Persistence \\
\hline & $\begin{array}{l}\text { No focus on actual mistake } \\
\text { but on the fact that a } \\
\text { student recognized the } \\
\text { mistake }\end{array}$ & $\begin{array}{l}\text { Fostering students' } \\
\text { process-focused thinking }\end{array}$ \\
\hline & $\begin{array}{l}\text { High expectations and } \\
\text { persistence }\end{array}$ & $\begin{array}{l}\text { Promoting mastery } \\
\text { orientation }\end{array}$ \\
\hline \multirow[t]{3}{*}{ The whole class } & $\begin{array}{l}\text { Give praise immediately } \\
\text { and concretely }\end{array}$ & \multirow[t]{3}{*}{$\begin{array}{l}\text { Fostering students' } \\
\text { process-focused thinking }\end{array}$} \\
\hline & High expectations & \\
\hline & $\begin{array}{l}\text { "The more we read, the more } \\
\text { competent you become" }\end{array}$ & \\
\hline
\end{tabular}

Mari explained in the STR interview that her intention with "not yet" feedback was to encourage Henri to continue a bit longer, while at the same time not to underestimate the work that the student had already done (see Dweck, 2010, p. 20). Mari believed that Henri could achieve more, so she gave him critical process-orientated feedback intended to encourage the student to pursue a better result (De Kraker-Pauw et al., 2017, p. 6). When she explained the pedagogical thinking behind her feedback practices, Mari expressed views that were in line with a growth-mindset pedagogy:

"Many of the first graders become impatient at the beginning of the autumn when they are not able to do things. For example, Henri was not able to read or write at all [when he started first grade], so he used to say very often 'I cannot do this. 'And what the child means by that is that 'I am not going to do this because I cannot because it is very hard and challenging. 'So, I have started or I willingly hasten to add: 'You 
cannot do it yet. 'I always like to add the words 'yet' to students' sentences. And then sometimes I will continue by saying 'the reason why we practise is so you will learn this'." (Critical incident 6, STR interview)

During classes, Henri often said that he was not able to do something. This happened when he was facing new and challenging things. Henri seemed to think that when something felt difficult, he preferred to say that he could not do it rather than just try. This kind of outlook represents a fixed mindset-motivated behaviour in which avoiding challenges is typical (see e.g. Dweck \& Leggett, 1988). Mari's experience was that behaviour like this hindered students' trying and putting effort into learning; in other words, she had identified how fixedmindset behaviour hampers the learning process (Rissanen et al., 2019). Mari wanted to disrupt this type of thinking and thus developed "not yet" practices. In her STR interview Mari also explained how her "not yet" feedback had had positive results with regards to Henri's behaviour. Henri himself had started to use the words 'not yet', described by Mari as follows:

"And guess what? Once I almost started crying when Henri was doing some exercise, and he was murmuring to himself: 'This is the dumbest exercise because I cannot do it yet', and he didn't realise that he was saying that, but he just kept on working." (Critical incident 6, STR interview)

This example shows how students learn to change their inner dialogue if their teacher provides coherent growth mindset messages. Mari's happiness in the change in Henri's inner talk also shows how much she wanted to promote positive change in her students. Her mission as a teacher was to teach her students the idea of learning through practising:

"When you repeat it [not yet] enough, it will transfer to the child. Not only to their speech but also to their thinking: 'I cannot do it yet, but I will practise and do this, so I will surely learn this. This is hard, but we will practise as long as is needed until you learn this'." (Critical incident 6, STR interview)

Mari's STR interview reveals that her growth mindset pedagogy consisted of a strong vision to foster students' process-focused thinking by teaching the positive role of putting forth effort, making mistakes and facing challenges in learning (see Rissanen et al., 2019, p. 206).

In another critical incident, Henri was practising writing the letter $\mathrm{J}$ and realised that he was writing it the wrong way; he then asked for the teacher's help. Mari reacted with following words:

"So now, you did a version that doesn't actually exist. Was it supposed to be a small or a big letter? Good that you noticed; you were very exact." (Critical incident 18, Observation data) 
As can be seen in Mari's comment, she did not focus on Henri's actual mistake but on the fact that he had recognised his mistake. Maris' process-orientated positive feedback on realising the mistake can motivate a student in the future to observe his learning process; it potentially encourages the student to be precise while working and correct mistakes as soon as he notices them (see Boaler, 2015). The critical incident also illustrates how Mari was promoting mastery orientation by fostering learning goals and maintaining high expectations. Mari acknowledged the reality, namely that Henri was not writing the letter as he was supposed to, but she praised Henri for perceiving the failure. In the STR interview Mari emphasised that her feedback was strongly connected with knowledge of the student. She wanted to strengthen Henri's learning process, as Henri's strength was not in writing nor was it in observing and developing his schoolwork. She specified that in her feedback she considered a student's earlier stage of development; she was pleased about Henri's improvement in concentration because it had been challenging for him.

The third critical incident with Henri happened at the end of the school day. Suddenly, Mari noticed that Henri had disappeared from his desk and was lying on the floor. Mari went over to him, knelt down and said:

"Excuse me, may I ask, Mister Virtanen, what are you doing under the table? Well, you have managed [during this class] very well. It will not be many minutes before we are will be finishing up." (Critical incident 1 , Observation data)

In her STR interview Mari explained that she knew Henri's strengths and weaknesses, and she wanted to take into consideration Henri's individual needs. Mari had wanted to leave a positive image for Henri about the good work he had already done, even though his action was improper at the time. Mari explained that she would not have let other students stay under a table, but knowing Henri's starting point she did not want to end Henri's school day with a negative comment. Before Henri started the first grade, his mother had told Mari:

"If Henri decides that he will not participate, then he will not." (Critical incident 1, STR interview)

This comment indicates the mother's fixed mindset beliefs about Henri. Mari explained that in the first school year Henri lay down in the corridor at the start of each day for the first two weeks of the term. Compared to his starting point, Henri was progressing well. Still, as this critical incident shows, Mari made an intervention right away when she noticed Henri's behaviour, and her pedagogical approach influenced the gradual changes in Henri's learning behaviour. Her immediate interventions in Henri's actions were also based on knowing his individual learning barriers which she wished to help him overcome (Rissanen et al., 2019). 


\subsection{Growth mindset in relation to the whole class}

Mari's growth mindset pedagogy was apparent in relation to the whole class (Table 1). She fostered students' process-focused thinking on a collective level by giving growth mindset messages in her feedback practices to the class as a whole. In the following critical incident, the lesson had been taught in a computer class, and the students had been practising how to use computers. The researcher did not observe or videotape this lesson, but she was present when the teacher gave feedback to the whole class about incidents in the computer class. When the lesson was over, everyone came back to their home classroom before recess. At that moment, Mari was standing in the doorway and said to everyone:

"I just praised you in there in the computer class very highly. You all survived very well. It was probably the best computer lesson of the whole year. This is so cool. You had such patience when you logged in, and many of you could even write your name, which made our work easier. Then things just happened, for example Kaapo's computer died, someone's [computer] started to update et cetera, but we cannot do anything about those things. No-one got nervous or angry, and we managed with patience." (Critical incident 15, Observation data)

This critical incident indicates how Mari gave process-focused feedback immediately after the lesson and in a very concrete way. She praised her students' behavioural choices, strategies and efforts (Rissanen et al., 2019, p. 206). Mari also had high expectations for her students, and she expressed her gratitude to the students and her hopes for the future in the following words:

"This is exactly the right way to work when there is only one adult and many students. Sometimes we just have to endure and wait. Today you did great job. I believe our last lesson will go as great as the previous one." (Critical incident 15, Observation data)

Mari seemed to use strategies that helped to mould students' growth mindsets by giving positive feedback, which she precisely targeted (Dweck, 2010) and which fostered students' process-focused thinking. Mari's feedback illustrated to the students which issues in their behaviour were praiseworthy; she wanted to teach them constructive life skills of persistence and patience. Hence, Mari seemed to verbalise and reinforce students' growth mindset behaviour. She let them know what kinds of actions were expected of them, indicating her high expectations. Mari explained in her STR interview that her deep desire was to praise students' strategies and efforts as often as possible, and give critical feedback when necessary (see Rissanen et al., 2019).

"Yes, I do give a lot of feedback; but also, when things go badly, I will say that aloud. For example, I might say 'this went very well' because that verifies their memory, and next time we do such a thing, the students know what they are expected to do and know what kind of behaviour they will be praised for." (Critical incident 15, STR interview) 
In another critical incident, Mari brought children's books to class. She had chosen a book for each student based on their individual reading skills. Before she began distributing the books, she said to the class:

"The more we learn to read, the more we will read real texts and also genuine stories here at school. The more we read, the more competent you become. And now we can start reading real stories and complete fairy tales." (Critical incident 21, Observation data)

Mari's statement describes how her appreciation of learning is demonstrated by her effort and persistence in repeating and practising actions that foster students' process-focused thinking (Rissanen et al., 2019). Simultaneously, Mari motivated students to keep on reading, because then they would be able to read the whole fairy tale, thereby teaching the value of effort and learning-to-learn skills (Rissanen et al., 2019). Mari's comment concisely expressed the results of persistent work for the entire autumn semester.

\section{Discussion}

In this article we presented an example of one teacher's growth mindset pedagogy. By observing and conducting STR interviews with an experienced teacher, Mari, we found that her growth mindset was actualised in her teaching practices in interactions with her students both individually and with the entire class collectively.

The main features of Mari's growth mindset pedagogy were illustrated on the individual level with the case of Henri, who had difficulty concentrating on his lessons. Henri's behaviour was identified as representing a fixed mindset which hindered his learning. We found that, in helping Henri, Mari had strong personal knowledge of his strengths and weaknesses, and she relied on this knowledge in formulating her pedagogical aims for him. This seemed to explain why she was able to intervene immediately when she noticed fixed-mindset behaviour in Henri's actions. She gave critical feedback in the form of 'not yet' phrases, and her process praise was focussed, not on Henri's mistakes, but on the fact that he recognised his mistakes. All in all, Mari showed high expectations and persistence in her interactions with Henri. Her efforts also seemed to be working, as Henri's fixed mindset-orientated behaviour and selftalk gradually changed during the autumn of his first year towards a growth mindset. In line with previous research, this teacher's consistently delivered growth mindset messages appeared to influence the formation of the student's growth mindset as well as his academic learning (Schmidt et al., 2015). At the very least Mari's growth mindset pedagogy set an example for her students to persist in the face of challenges and obstacles. In this kind of safe atmosphere students dare to make mistakes because they are not afraid of the teacher's reactions (see Boaler, 2015). Intervening in students' fixed-mindset behaviour and using 'not yet' feedback were essential components of Mari's growth mindset pedagogy. These strategies were unique to Mari compared to previously studied Finnish teachers with a growth mindset (Rissanen et al., 
2018a; Rissanen, Kuusisto, Hanhimäki, \& Tirri, 2018b; Rissanen et al., 2019). Mari's growth mindset pedagogy was also actualised in her interactions with the class as a whole. Fostering students' process-focused thinking (Rissanen et al., 2019) was typical of Mari, a practice seen in her feedback, which for example praised students' courage and strategies and fostered their incremental beliefs about learning.

However, it is worth noticing to acknowledge the limitations of the current study. We investigated only one teacher's growth mindset in one classroom. Hence, these results cannot be generalised. However, the study does offer both a deep understanding and examples of how growth mindset pedagogy can be implemented in real classrooms. Yet, the question can be raised whether the number of critical incidents ( 17 in all) during one week is sufficient evidence of a teacher's growth mindset. Seventeen mindset-related incidents are not a very rich number. However, these incidents clearly embodied a growth mindset pedagogy in action. The study also indicates equivalence between the mindsets identified using Dweck's (2000) inventory and classroom practices (Rissanen et al., 2018a, 2018b, 2019), even though the reliability of investigating the actualisation of an individual teacher's growth mindset on the basis of a mindset scale can be questioned.

\section{Implications}

The results of the present study support our view that a teacher's growth mindset plays an important role in educational practices. Thus, for advancing research on teachers' growth mindset pedagogy in a classroom environment, it is essential to widen the understanding of implicit beliefs and their influence on the teaching practices that are needed in teacher education programmes. However, more studies are needed on how teachers' growth mindset pedagogy is actualised in classroom environments at different levels of education and educational systems. Additionally, research on actualisation of growth mindset pedagogy in different countries would offer comparable information of contingent cultural differences or similarities. Nevertheless, the results of this study can be used in educating pre-service and in-service teachers to adopt good practices of growth mindset pedagogy and to foster a growth mindset among their students. This study may also give tools for school leaders to observe and use practices of growth mindset pedagogy in their school environment. For example, noticing the importance of constructive feedback and supporting teachers'and students' individual learning processes are key factors of the growth mindset pedagogy (Rissanen et al., 2019).

\section{Conclusion}

The present study was conducted in the University of Helsinki's Viikki Teacher Training School. Every year hundreds of Finnish teachers do their practice teaching in Viikki. Like Mari, the school's teachers are expected to exemplify the best teaching practices and influence Finnish society positively by mentoring and guiding future teachers. Mari's teaching offers an example for Finnish 
student teachers. In addition, through studies like the present one, her strategies and pedagogical thinking can be utilised in teacher education programmes to demonstrate how growth mindset pedagogy can be implemented in classrooms. Nevertheless, the results of this study indicate the continuing need for qualitative research to identify the implications of teachers' mindsets in the classroom environment. With the most up-to-date research-based education, teachers have the potential to change their teaching practices in a way that supports the development of growth mindset in their students.

\section{Funding}

This work was supported by the European Regional Union Development Fund and the Republic of Estonia under the Grant Dora Plusactivity 2.1.

\section{Disclosure statement}

No potential conflict of interest was reported by the authors.

\section{References}

Blackwell, L. S., Trzesniewski, K. H. \& Dweck, C. S. (2007). Implicit theories of intelligence predict achievement across an adolescent transition: A longitudinal study and an intervention. Child development, 78(1), 246-263. doi:10.1111/j.14678624.2007.00995.x

Boaler, J. (2015). Mathematical mindsets: Unleashing students' potential through creative math, inspiring messages and innovative teaching. San Francisco, CA: Jossey-Bass. doi:10.1080/14794802.2016.1237374

De Kraker-Pauw, E., Van Wesel, F., Krabbendam, L. \& Van Atteveldt, N. (2017). Teacher mindsets concerning the malleability of intelligence and the appraisal of achievement in the context of feedback. Frontiers in Psychology, 8, 1-13. doi:10.3389/fpsyg.2017.01594

Dweck, C. S. (2000). Self-theories: Their role in motivation, personality and development. New York, London: Psychology Press.

Dweck, C. S. (2006). Mindset: The new psychology of success. New York, NY: Random House.

Dweck, C. S. (2010). Even geniuses work hard why foster a growth mindset? Creating a culture of risk taking building a growth mindset. Educational Leadership, 68(1), 16-20.

Dweck, C. S. \& Leggett, E. L. (1988). A social-cognitive approach to motivation and personality. Psychological Review, 95(2), 256-273. doi:10.1037//0033-295x.95.2.256

Elo, S., \& Kyngäs, H. (2008). The qualitative content analysis process. Journal of Advanced Nursing, 62(1), 107-115. doi:10.1111/j.1365-2648.2007.04569.x

Huang, L. S. (2014). Video-stimulated verbal recall: A method for researching cognitive processes and strategic behaviors. In SAGE Research Methods Cases. (pp. 1-22). London: SAGE Publications. doi:10.4135/978144627305013508883

Kamins, M. L. \& Dweck, C. S. (1999). Person versus process praise and criticism: implications for contingent self-worth and coping. Developmental Psychology, 35(3), 835-847. doi:10.1037//0012-1649.35.3.835

Klem, A. M. \& Connell, J. P. (2004). Relationships matter: Linking teacher support to student engagement and achievement. Journal of school health, 74(7), 262-273. doi:10.1111/j.1746-1561.2004.tb08283.x

Kristjánsson, K. (2008). Education and self-change. Cambridge journal of education, 38(2), 


\section{7-230. doi:10.1080/03057640802063320}

Kuusisto, E., Laine, S. \& Tirri, K. (2017). How do school children and adolescents perceive the nature of talent development? A case study from Finland. Education Research International, 2017, 1-8. doi:10.1155/2017/4162957

Malinen, O. P., Väisänen, P. \& Savolainen, H. (2012). Teacher education in Finland: a review of a national effort for preparing teachers for the future. Curriculum Journal, 23(4), 567-584. doi:10.1080/09585176.2012.731011

Mangels, J. A., Butterfield, B., Lamb, J., Good, C. \& Dweck, C. S. (2006). Why do beliefs about intelligence influence learning success? A social cognitive neuroscience model. Social cognitive and affective neuroscience, 1(2), 75-86. doi: $10.1093 /$ scan/ns1013

National Core Curriculum for basic education. (2016). Helsinki: Finnish National Board of Education.

Paunesku, D. (2013). Scaled-up social psychology: Intervening wisely and broadly in education (Doctoral dissertation). Stanford University, Stanford, CA.

Rattan, A., Good, C. \& Dweck, C. S. (2012). "It's ok - Not everyone can be good at math": Instructors with an entity theory comfort (and demotivate) students. Journal of Experimental Social Psychology, 48(3), 731-737. doi:10.1016/j.jesp.2011.12.012

Rissanen, I., Kuusisto, E., Hanhimäki, E. \& Tirri, K. (2018a). Teachers' implicit meaning systems and their implications for pedagogical thinking and practice: A case study from Finland. Scandinavian Journal of Educational Research, 62(4), 487-500. doi:10.1080/00313831.2016.1258667

Rissanen, I., Kuusisto, E., Hanhimäki, E. \& Tirri, K. (2018b). The implications of teachers' implicit theories for moral education: A case study from Finland. Journal of Moral Education, 47(1), 62-76. doi:10.1080/03057240.2017.1374244

Rissanen, I., Kuusisto, E., Tuominen, M. \& Tirri, K. (2019). In search of a growth mindset pedagogy: A case study of one teacher' $\mathrm{s}$ classroom practices in a Finnish elementary school. Teaching and Teacher Education, 77, 204-213. doi:10.1016/j.tate.2018.10.002

Sahlberg, P. (2007). Education policies for raising student learning: the Finnish approach. Journal of Education Policy, 22(2), 147-171. doi:10.1080/02680930601158919

Sahlberg, P. (2014). Finnish lessons: What can the world learn from educational change in Finland? New York, NY: Teachers College Press.

Schmidt, J. A., Shumow, L. \& Kackar-Cam, H. (2015). Exploring teacher effects for mindset intervention outcomes in seventh-grade science classes. Middle Grades Research Journal, 10(2), 17-32.

Soini, T., Pietarinen, J. \& Pyhältö, K. (2016). What if teachers learn in the classroom ? Teacher Development, 20(3), 380-397. doi:10.1080/13664530.2016.1149511

Shulman, L. S. (1986). Paradigms and research programs in the study of teaching: A contemporary perspective. In M. Wittrock (Ed.), Handbook of research on teaching (3rd ed., pp. 3-33). New York, NY: Macmillan.

Tirri, K. (2014). The last 40 years in Finnish teacher education. Journal of Education for Teaching, 40(5), 600-609. doi:10.1080/02607476.2014.956545

Yeager, D. S. \& Dweck, C. S. (2012). Mindsets that promote resilience: When students believe that personal characteristics can be developed. Educational Psychologist, 47(4), 302-314. doi:10.1080/00461520.2012.722805 